(RESEARCH ARTICLE)

\title{
Relationship of the gingival margin of restorations in respect to the biologic width
}

Jain Atul, Sharma Anjali *, Bahuguna Rachana, Siddiqui Arif and Dalai Sasmita

Chandra Shekar Sharma, Tulsi Bhawan, Near Raj Rajeshwar Temple, Jaiganj, Aligarh (202001), Uttar Pradesh.

Publication history: Received on 25 February 2020; revised on 02 March 2020; accepted on 06 March 2020

Article DOI: https://doi.org/10.30574/wjarr.2020.5.3.0051

\begin{abstract}
Placement of gingival margins of different type of restorations has to be varied as per the extent of the defect and the restorative demands. Various factors tends to govern the margin placement. Over the years, as per the level of the free gingiva, restorative margins has been described as supra gingival, equigingival and subgingival. The concept of biologic width becomes important regarding the margin placement. This short communication discusses the concept of biologic width and the gingival margins of different restorations in respect to this concept.
\end{abstract}

Keywords: Biologic width; Restorative margin placement; Violation of biologic width

\section{Introduction}

Maintenance of gingival health is essential for periodontal integrity.[1] Many a times, restorative treatment is carried out without giving adequate importance to the surrounding gingival location. Such restorations both direct as well as indirect, could have far reaching adverse consequences. In order to maintain their optimal health, knowledge of gingival attachments and their interrelationship with the restorative margins becomes essential.[2]

\section{Biologic width}

Biologic width has been a debatable topic for the last 4-5 decades. Earlier it was considered a band of soft tissue encircling and attaching the gingiva with the cervical margin of the tooth [3]. The ideal average gingival sulcus depth is $0.69 \mathrm{~mm}$. Established dimension of junctional epithelium is $0.97 \mathrm{~mm}$, while that of connective tissue is $1.07 \mathrm{~mm}$, thus biologic width is $2.04 \mathrm{~mm}$ [2].

The biologic width varies from tooth to tooth, and also from one surface of the tooth to another [4].

\subsection{Importance of biologic width}

Maintaining the biologic width is important because of the following reasons-

1) Maintenance of gingival sulcular health

2) Maintenance of healthy periodontium

\subsection{Violation of biologic width}

Biologic width is not to be encroached upon but generally it is violated in 2 situations-

\footnotetext{
${ }^{*}$ Corresponding author: Sharma Anjali
} 
1) Where the tooth defect/lesion is at the gingival margin or sub gingival.[5]

2) In anterior teeth, where due to aesthetic reasons, the margin has to be placed sub gingival.[5].

\subsection{Consequences of biologic width violation}

Once the biologic width is violated following could follow-Gingival Inflammation [4], Gingival Recession [4], Bleeding on probing [4], Bone loss [4], Leads to clinical attachment loss [4], Increased mobility of involved teeth [3].

\section{Restorative margin placement}

Three type of margins can be placed while carrying out the restorations. They are -

\subsection{Supragingival margin}

It is placed above the level of marginal gingiva. This margin has been used for non-esthetic areas or when visibility of cervical third is not present, when the defect is above the marginal gingiva.

\subsubsection{Advantages}

Easy to prepare, Easy Duplication of margin, Exact replication of margin of restoration, Exact finishing and polishing of margins, Non/ least irritating

\subsubsection{Disadvantages}

Unaesthetic, Differentiation between the tooth and restoration is obvious.

\subsubsection{Materials}

Supragingival margins can be placed when the following materials are used - Layered and pressed feldspathic porcelain, All ceramic (Zirconia-in non-aesthetic areas), Composite, Gold for posterior teeth restoration, Amalgam restoration(Posterior teeth), GIC, Compomer.

\subsection{Subgingival margin}

It is placed below the level of marginal gingiva.

\subsubsection{Advantages}

More esthetic.

\subsubsection{Disadvantages}

Most irritating to the periodontium, Highest occurrence of periodontitis, Most difficult to maintain.

\subsubsection{Materials}

Porcelain fused to metal, Gold for posterior tooth restoration.

\subsection{Equigingival margin}

It is placed at the level of marginal gingiva.

\subsubsection{Advantages}

Less impact on periodontium,Conservation of tooth structure, Esthetic goals can be achieved

\subsubsection{Disadvantages}

Higher plaque accumulation, higher possibility of gingivitis

\subsubsection{Materials}

Zirconia (in aesthetic areas) 


\section{Guidelines regarding restorative margin placement}

For placement of the gingival margins of the restorations following guidelines have to be followed Supragingival margin placement, When defect is at the gingival margin, For enhanced esthetics

When defect extends below the gingival margin- If probing depth is $1.5 \mathrm{~mm}$ or less, the restorative margin could be placed $0.5 \mathrm{~mm}$ below the marginal gingiva.[4] If probing depth is $>1.5 \mathrm{~mm}$ but less than $2 \mathrm{~mm}$, the restorative margin can be placed at half the depth of sulcus.[4] If probing depth is $>2 \mathrm{~mm}$, gingivectomy can be done to create $1.5 \mathrm{~mm}$ sulcus depth. Then the restorative margin can be placed $0.5 \mathrm{~mm}$ below the marginal gingiva.[4]

\section{Discussion}

As a consequence of numerous restorations, research has pointed towards the best gingival margin, as the one which is distant from the gingival margin. This finding has been widely accepted because of the fact that the maintenance of such margins is easy and quite durable.[2] Supragingival margins do not lead to enhanced plaque/calculus accumulations.[6] Moreover the possibility of secondary caries is negligible due to direct hygiene procedures, possible with these margins. These margins, being distant from the gingival fluid do not lend themselves to a higher rate of dissolution.[7] Jackob and Leif in their study found that when supra gingival margins are placed, gingival health is improved.[2]Their finishing is superior since the used restorative material can be accessed without any hindrance.[8] DHANRAJ et al on the basis of systemic review and meta-analysis found that supragingival margins are better than subgingival margins.[9]

Placement of subgingival margins is complicated because of presence of the free marginal gingiva.[10] This situation can be overcome by employing a retraction cord.[11]Jackob and Leif found that margins tend to accumulate plaque and calculus to a higher extent, degree and deteriorate rapidly.[12]

To overcome the challenges associated with finishing, as well as maintaining the subgingival margins, equigingival margin was proposed. These can be prepared relatively easily than the subgingival margin.[6] Esthetics is easily achieved, and they are easier to maintain.[6,13] In separate studies Aboelsaad and Babitha, found equigingival margin to perform better than subgingival over a prolonged period of time.[6,13]

\section{Conclusion}

Well designed and properly adapted restorative margin placed in consonance with the aesthetic and functional need depends upon patient motivation and cooperation. Depending upon the clinical situation one of the three i.e supra, sub and equigingival margins should be selected and placed so as to maintain and preserve the biologic width.

\section{Compliance with ethical standards}

\section{Disclosure of conflict of interest}

None.

\section{References}

[1] N Antonio and B Dieter. (2000). Structure of periodontal tissues in health and disease. Journal of Periodontology, 40(1), 11-28.

[2] S Anupama, V Rangarajan, S Ravindra and S Preeti. (2011). Biologic perspectives in restorative treatment. Journal Indian Prosthodontic Society, 11(3), 143-148.

[3] RM Ahsan et al. (2019). Biologic width. Considering periodontium in restorative dentistry, 6(3), 5-11.

[4] M Aishwarya and G Sivaram. (2015). Biologic width concept and violation. SRM Journal of Research in Dental Sciences, 6(4), 250-256.

[5] B Curtis and K Wayne. (1981). Current theories of crown contour, margin placement, and pontic design. The journal of prosthetic dentistry, 45(3), 268-277. 
[6] Aboelsaad Nayer, Rayyan, Osman and Badr. (2012). Biologic width and its importance in periodontal and restorative dentistry. Journal of Conservative Dentistry, 15(1), 12-17.

[7] S Syed, N Kumuda, G Veenadharini, C Sachidananda and W Ambica. (2015). Iatrogenic Damage to Periodontium by Restorative Treatment Procedures: An Overview. The Open Dentistry Journal, 9(1), 217-222.

[8] S Arvind, S Nina and B Roopa. (2012). Periodontal considerations determining the design and location of margins in restorative dentistry. Journal of Interdisciplinary Dentistry, 2(1), 3- 10.

[9] M Dhanraj. (2017). Effect of sub-gingival margins influencing periodontal health - a systematic review and meta-analysis. Biomed. \& Pharmacol. J, 10(2), 739-747.

[10] Padbury Jr A, Eber R and Wang H-L. (2003). Interactions between the gingiva and the margin of restorations. Journal of Clincal Periodontol, 30, 379-385.

[11] P Sushma, Marawar, B Girish, L Sanjay and K Jitendra. (2010). Effect of retraction materials on gingival health: A histopathological study. Journal of Indian Society of Periodontology, 14(1), 35-39.

[12] V Jackob and H Leif. (1977). Oral hygiene in a group of supervised patients with fixed prostheses. Journal of Periodontology, 48(4), 221-224.

[13] N Aboelsaad, Rayyan, Osman and Badr. (2011). An update on the effect of crown margin locations and materials on periodontal health. Egyptian Dental Journal, 58(4), 3640- 3644.

\section{How to cite this article}

Jain A, Sharma A, Bahuguna R, Siddiqui A and Dalai S. (2020). Relationship of the gingival margin of restorations in respect to the biologic width. World Journal of Advanced Research and Reviews, 5(3), 44-47. 